\title{
Dopamine Partial Agonist Reverses Amphetamine Withdrawal in Rats
}

\author{
Cristina Orsini, Ph.D., George F. Koob, Ph.D. and Luigi Pulvirenti, M.D.
}

Decreased motivation to work for a natural reward is a sign of amphetamine withdrawal and is thought to be associated with hypofunction of the mesolimbic dopamine system.

During withdrawal from repeated amphetamine

administration, rats showed reduced responding for a sweet solution in a progressive ratio schedule. Repeated systemic treatment with terguride ( 0.2 and $0.4 \mathrm{mg} / \mathrm{kg}$, i.p.) twice daily during the first four days of amphetamine withdrawal reversed the decrease in responding for the sweet solution. These results suggest that dopamine partial agonists, possibly due to their agonistic-like actions under these conditions, are a potential therapeutic approach for the acute withdrawal stage of the amphetamine addition cycle.

[Neuropsychopharmacology 25:789-792, 2001] (C) 2001 American College of Neuropsychopharmacology. Published by Elsevier Science Inc.
KEY WORDS: Dopamine; Partial agonist; Amphetamine; Withdrawal; Terguride; Dependence

Psychostimulant withdrawal in humans is associated with fatigue, depression of mood, anhedonia, and psychomotor retardation and is a critical component of the dependence cycle, but no pharmacotherapeutic treatments are currently available for psychostimulant withdrawal. In rats, psychomotor retardation and decreased motivation to work for a natural reward are signs of amphetamine withdrawal (Pulvirenti and Koob 1993; Barr and Phillips 1999). Although dopamine (DA) mesolimbic neurotransmission appears to be critically involved in psychostimulant dependence (Wise and Bozarth 1987; Wise 1996; Koob and Le Moal 1997), only

From the Department of Neuropharmacology The Scripps Research Institute (CO, GFK, LP) and Claude Bernard Neuroscience Institute (LP), La Jolla, CA.

Address correspondence to: Luigi Pulvirenti, M.D., Department of Neuropharmacology CVN-7, The Scripps Research Institute, 10550 North Torrey Pines Rd., La Jolla, CA 92037.

Received August 26, 2000; revised April 6, 2001; accepted April 17, 2001.

Online publication: 4/19/01 at www.acnp.org/citations/Npp 041901108. limited efficacy has been reported in both preclinical models and clinical trials with dopamine agonists and antagonists (for review see Withers et al. 1995; Mello and Negus 1996).

Partial dopamine agonists bind to the dopamine receptor with high affinity but low intrinsic activity (Hoyer and Boddeke 1993), and have been hypothesized to act as functional antagonists in conditions of high dopaminergic tone and as functional agonists in conditions of DA depletion (Clark et al. 1991; Svensson et al. 1991; Pulvirenti and Koob 1994). Within the context of drug dependence, the DA D2 receptor partial agonists terguride and SDZ 208-911 showed activity as functional antagonists in rats trained to self-administer cocaine and amphetamine under different schedules (Pulvirenti and Koob 1994; Pulvirenti et al. 1998; Izzo et al. 2001). However, DA partial agonists might restore the relative functional hypoactivity of the dopamine system during psychostimulant withdrawal (Pulvirenti and Koob 1994).

The aim of the present study was to investigate the effects of terguride using a model of amphetamine withdrawal (Barr and Phillips 1999) from sustained, high doses of amphetamine shown to produce a decrease in operant responding for a sweet solution. 


\section{METHODS}

This study was performed in accordance with the National Institutes of Health Guide for the Care and Use of Laboratory Animals. Male Wistar rats (Charles River) were housed on a reversed light/dark cycle (lights on $10 \mathrm{PM}$ to $10 \mathrm{AM})$. Testing was performed between $2 \mathrm{PM}$ and 4 PM. Following an initial 48-h exposure to a sweet solution [ $3 \%$ sucrose (Fisher Scientific) and $0.125 \%$ saccharin (Sigma Chemical Co), all rats were waterdeprived for $20 \mathrm{~h}$ daily before being placed in standard operant chambers (Coulburn Instruments) (Roberts et al. 2000). Subjects were placed on a progressive-ratio (PR) schedule for the sweet solution $(0.1 \mathrm{ml}$ per reinforcer) for $2 \mathrm{~h}$ daily [following initial training on a fixed-ratio (Barr and Phillips 1999)] and the response requirement increased according to the following progression: $1,3,6,10,15,20,25,32,40,50,62,77,95,118$, $145,175,205,235,265$, etc.

The breaking point (BP) was defined as the last ratio attained prior to a $1-\mathrm{h}$ period during which a ratio was not completed. When stable responding was achieved ( $\pm 10 \%$ of reinforcements within three consecutive days and $\mathrm{BP}>16$ ) the rats were injected intraperitoneally (i.p.) three times per day (9 AM, 5 $\mathrm{PM}$, and $12 \mathrm{AM}$ ), starting with a dose of $1 \mathrm{mg} / \mathrm{kg}$ of amphetamine and increasing by $1 \mathrm{mg} / \mathrm{kg}$ per injection for 10 injections (Barr and Phillips 1999). After the last injection of amphetamine the rats were treated i.p. twice daily (9:30 AM and 9:30 PM) for four days with either saline $(n=13)$ or terguride at the dose of $0.2(n=10)$ or $0.4 \mathrm{mg} / \mathrm{kg}(n=10)$. PR responding was monitored for the first four days of withdrawal (Pulvirenti and Koob 1993; Barr and Phillips 1999).

A separate group of rats was trained as described and exposed to three days of saline administration according to the same amphetamine schedule described above. These rats then were treated with an effective dose of terguride $(0.2 \mathrm{mg} / \mathrm{kg} ; n=7)$ and PR responding was monitored as in the above experiment. Doses and schedules of terguride administration were chosen according to previous studies (Pulvirenti and Koob 1993; Pulvirenti et al. 1998).

Terguride (Research Biochemicals International) was dissolved in distilled water and $1 \mathrm{~N} \mathrm{HCl}$, and $\mathrm{pH}$ adjusted to 5.5 with $1 \mathrm{M} \mathrm{NAOH}$. d-amphetamine sulfate (Sigma) was dissolved in saline and all drugs were injected in a volume of $1.0 \mathrm{ml} / \mathrm{kg}$. Data analyses were performed using analysis of variance (ANOVA) as described by Pulvirenti and Koob (1993). First an overall analysis was performed to directly explore differences between treatment groups. This was followed by comparison at the various levels to explore at what time point (day) statistical significance was reached. Posthoc Tukey's test was used where appropriate.

\section{RESULTS}

Figure 1 shows the effects of treatment with terguride on PR responding for a sweet solution. Overall ANOVA revealed that there was a significant difference between treatment groups: treatment with terguride prevented the reduction of $\mathrm{BP}$ (expressed as total reinforcement earned) in rats treated with amphetamine $[\mathrm{F}(2,162)=$ $3.296, p<.05$ ] and post-hoc analysis revealed that statistical significance was reached for the dose of terguride $0.4 \mathrm{mg} / \mathrm{kg}$ ( $p<.05 \mathrm{vs}$. saline, Tukey's test). In addition, comparison at the various levels revealed a significant reduction of BP (expressed as total reinforcement earned) in rats treated with amphetamine and saline $[\mathrm{F}(4,48)=3.98, p<.01]$ and statistical significance was reached during the first two days of withdrawal $(p<$ .01, Tukey's test).

ANOVA revealed no significant reduction of breaking point in rats treated with amphetamine and terguride at the doses of $0.2 \mathrm{mg} / \mathrm{kg}[\mathrm{F}(4,36)=1.74, \mathrm{NS}]$ and $0.4 \mathrm{mg} / \mathrm{kg}[\mathrm{F}(4,36)=2.59$, NS $]$. Finally, Tukey's test revealed a significant difference between terguride at the

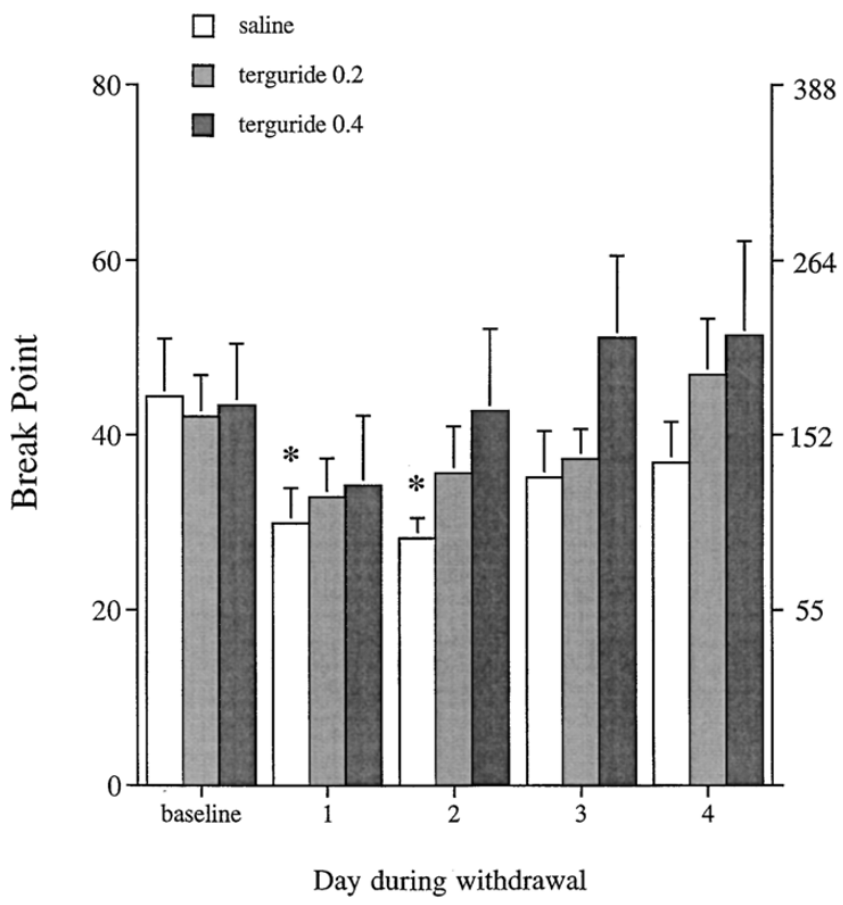

Figure 1. Effect of repeated treatment with terguride ( 0.2 and $0.4 \mathrm{mg} / \mathrm{kg}$, i.p. twice daily for four days) on responding for a sweet solution ( $3 \%$ sucrose $+0.125 \%$ saccharin) under a progressive-ratio schedule of reinforcement. Values represent means \pm SEM of breaking points and cumulative total responses (right) (saline, $n=13$; terguride $0.2 \mathrm{mg} / \mathrm{kg}, n=$ 10; terguride $0.4 \mathrm{mg} / \mathrm{kg}, n=10) .{ }^{*} p<.01$ Tukey's test vs. baseline following significant ANOVA. Tukey's test also revealed a significant difference between terguride at the dose of $0.4 \mathrm{mg} / \mathrm{kg}$ and saline at Days 2,3 , and $4(p<.05)$ but not at Day 1 (not indicated). 
Table 1. Effects of Repeated Treatment with Terguride on Progressive-Ratio Responding for a Sweet Solution in Rats Not Previously Exposed to Amphetamine

\begin{tabular}{cccccc}
\hline & & \multicolumn{5}{c}{ Day } \\
\cline { 3 - 6 } & Baseline & $\mathbf{1}$ & $\mathbf{2}$ & $\mathbf{3}$ & $\mathbf{4}$ \\
\hline $\begin{array}{c}\text { Terguride } \\
(0.2 \mathrm{mg} / \mathrm{kg})\end{array}$ & \pm .4 & 7.6 & 7.4 & 7.0 & 7.4 \\
\hline
\end{tabular}

Values represent means \pm SEM of breaking points $(n=7)$.

dose of $0.4 \mathrm{mg} / \mathrm{kg}$ and saline at Days 2, 3, and $4(p<$ .05) but not at Day 1.

Table 1 shows that terguride did not significantly modify the total reinforcement earned on PR responding for a sweet solution in animals not previously exposed to amphetamine $[\mathrm{F}(4,24)<1, \mathrm{NS}]$.

\section{DISCUSSION}

The present results show that amphetamine withdrawal is associated with decreased motivation to respond for a sweet solution as measured by a reduced breaking point in a progressive-ratio schedule, thus confirming previous results (Barr and Phillips 1999). Systemic treatment with the dopamine partial agonist terguride restored responding for the sweet solution. Terguride by itself did not modify basal responding for a sweet solution in rats not exposed to amphetamine, thus ruling out possible non-specific effects of the partial agonist on the behavior under test. The results suggest that a dopamine partial agonist may have potential use as a treatment for the motivational effects of acute or protracted abstinence from psychostimulant drugs.

The early phase of psychostimulant withdrawal is characterized by a depressive state in humans and is thought to be associated with DA hypoactivity within the mesolimbic system (Imperato et al. 1992; Parsons et al. 1991; Rossetti et al. 1992; Weiss et al. 1992). In conditions of low DA tone, partial agonists show agonistic properties (Clark et al. 1991; Svensson et al. 1991) and terguride prevented symptoms of abstinence during amphetamine withdrawal similar to a full dopamine agonist (Pulvirenti and Koob 1993). In contrast, during acute exposure to amphetamine, the effects of terguride on PR responding for the drug are similar to those of the full DA antagonist raclopride and different from those of the full agonist quinpirole (Izzo et al. 2001).

It is also interesting that the effects of terguride in the present study appear to become more pronounced after repeated administration. On the contrary, in a study with similar design investigating the effects of the full dopamine agonist lisuride on amphetamine withdrawal (Pulvirenti and Koob 1993), the preventive ef- fects of lisuride on psychomotor retardation were evident since the first day of treatment. The reason for these differences is not presently clear, although it is possible that since terguride is a partial agonist its stimulatory effects on dopamine function may require repeated treatment to develop.

Although psychomotor retardation is also a component of amphetamine withdrawal (Paulson et al. 1991; Pulvirenti and Koob 1993), it is unlikely that motor impairment is solely responsible for the effects reported here and previously (Barr and Phillips 1999). Indeed rats have been shown to maintain high rates of operant responding for intracranial self-stimulation during psychostimulant withdrawal (Markou and Koob 1992). Additionally, the pattern of sucrose consumption reported by Barr and Phillips (1999) did not resemble the pattern of consummatory behavior observed after administration of motor-impairing doses of dopamine antagonists (Fowler and Mortell 1992).

\section{ACKNOWLEDGMENTS}

This is publication number 13494-NP from The Scripps Research Institute. This work was partially supported by National Institutes of Health grant DA 10072 from the National Institute on Drug Abuse. The authors wish to thank Drs. R. Horowski and J. Polich for helpful discussion and Mike Arends for editorial assistance.

\section{REFERENCES}

Barr AM, Phillips AG (1999): Withdrawal following repeated exposure to d-amphetamine decreases responding for a sucrose solution as measured by a progressive ratio schedule of reinforcement. Psychopharmacology 141:99-106

Clark D, Furmidge LJ, Petry N, Tong ZY, Ericsson M, Johnson D (1991): Behavioural profile of partial D2 dopamine receptor agonists. I. Atypical inhibition of d-amphetamine-induced locomotor hyperactivity and stereotypy. Psychopharmacology 105:381-392

Fowler SC, Mortell C (1992): Low doses of haloperidol interfere with rat tongue extension during licking: a quantitative analysis. Behav Neurosci 106:386-395

Hoyer D, Boddeke HWGM (1993): Partial agonists, full agonists, antagonists: Dilemmas of definition. Trends Pharmacol Sci 14:270-275

Imperato A, Mele A, Scrocco MG, Puglisi-Allegra S (1992): Chronic cocaine alters limbic extracellular dopamine. Neurochemical basis for addiction. Eur J Pharmacol 212:299-300

Izzo E, Orsini C, Koob GF, Pulvirenti L (2001): A dopamine partial agonist and antagonist block amphetamine selfadministration in a progressive ratio schedule. Pharmacol Biochem Behav 68:701-708

Koob GF, Le Moal M (1997): Drug abuse: Hedonic homeostatic dysregulation. Science 278:52-58 
Markou A, Koob GF (1992): Bromocriptine reverses the elevation in intracranial self-stimulation thresholds observed in a rat model of cocaine withdrawal. Neuropsychopharmacology 7:213-224

Mello NK, Negus SS (1996): Preclinical evaluation of pharmacotherapies for treatment of cocaine and opioid abuse using drug self-administration procedures. Neuropsychopharmacology 14:375-424

Parsons LH, Smith AD, Justice JB Jr (1991): Basal extracellular dopamine is decreased in the rat nucleus accumbens during abstinence from chronic cocaine. Synapse 9:60-65

Paulson PE, Camp DM, Robinson TE (1991): Time course of transient behavioral depression and persistent behavioral sensitization in relation to regional brain monoamine concentrations during amphetamine withdrawal in rats. Psychopharmacology 103:480-492

Pulvirenti L, Koob GF (1993): Lisuride reduces psychomotor retardation during withdrawal from chronic intravenous amphetamine self-administration in rats. Neuropsychopharmacology 8:213-218

Pulvirenti L, Koob GF (1994): Dopamine receptor agonists, partial agonists and psychostimulant addiction. Trends Pharmacol Sci 15:374-379

Pulvirenti L, Balducci C, Piercy M, Koob GF (1998): Characterization of the effects of the partial dopamine agonist terguride on cocaine self-administration in the rat. J Pharmacol Exp The 286:1231-1238
Roberts AJ, Heyser CJ, Cole M, Griffin P, Koob GF (2000): Excessive ethanol drinking following a history of dependence: Animal model of allostasis. Neuropsychopharmacology 22:581-594

Rossetti ZL, Hmaidan Y, Gessa GL (1992): Marked inhibition of mesolimbic dopamine release: A common feature of ethanol, morphine, cocaine and amphetamine abstinence in rats. Eur J Pharmacol. 221:227-234

Svensson K, Ekman A, Piercey MF, Hoffmann WE, Lum JT, Carlsson A (1991): Effects of the partial dopamine receptor agonists SDZ 208-911, SDZ 208-912 and terguride on central monoamine receptors: A behavioral, biochemical and electrophysiological study. NuanynSchmiedeberys Arch Pharmacol 344:263-274

Weiss F, Markou A, Lorang MT, Koob GF (1992): Basal extracellular dopamine levels in the nucleus accumbens are decreased during cocaine withdrawal after unlimited-access self-administration. Brain Res 593:314-318

Wise RA (1996): Neurobiology of addiction. Curr Opin Neurobiol 6:243-251

Wise RA, Bozarth MA (1987): A psychomotor stimulant theory of addiction. Psychol Rev 94:469-492

Withers NW, Pulvirenti L, Koob GF, Gillin JC (1995): Cocaine abuse and dependence. J Clin Psychopharmacol 15:63-78 